\title{
Analysis of economic development of Ukraine regions based on taxonomy method
}

\author{
Uliana Andrusiv ${ }^{a^{*}}$, Lilya Simkiva, Olena Dovgal ${ }^{b}$, Nataliia Demchuk ${ }^{c}$, Nataliia Potryvaieva ${ }^{b}$, An- \\ zhela Cherchata $^{d}$, Iryna Popadynets ${ }^{a}$, Ganna Tkachenko ${ }^{c}$, Olena Serhieieva ${ }^{\mathrm{e}}$ and Halyna Sydor $^{\mathrm{f}}$
}

\author{
${ }^{a}$ Ivano-Frankivsk National Technical University of Oil and Gas, Ukraine \\ ${ }^{b}$ Mykolayiv National Agrarian University (9, Georgiya Gongadze, Ukraine \\ ${ }^{c}$ Dnipro State Agrarian and Economics University, Ukraine \\ ${ }^{d}$ State Higher Educational Institution, Pridneprovsk State Academy of Civil Engineering and Architecture, Ukraine \\ eAlfred Nobel University, Ukraine

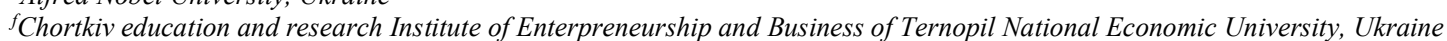

\section{H R O N I C L E A B S T R A C T}

\begin{tabular}{l}
\hline Article history: \\
Received: August 192019 \\
Received in revised format: Au- \\
gust 192019 \\
Accepted: September 27, 2019 \\
Available online: \\
September 27, 2019 \\
\hline Keywords: \\
Regional activity \\
Taxonomy method \\
Integral indicator \\
Comparative analysis \\
Ukraine
\end{tabular}

\begin{abstract}
The purpose of the article is to assess the impact of the investment and innovation components on the economic development of Ukraine regions using the taxonomy method. The proposed method allows determining the object state level in a general set of objects, and ordering the objects according to growth or decrease of the indicators. The article substantiates the necessity to assess the dynamics of the regional economic development level in order to identify the reserves and capacities for increasing profitability and efficiency of further activities. The integral indicator of the regions' development level is calculated. The comparative analysis is carried out within the framework of the proposed model. The research results suggest that the proposed model enables us to trace the causes of the negative phenomena occurrence in the activities of the regions, to prevent their occurrence, and to develop complex managerial influences to provide the state with a vector of positive development.
\end{abstract}

(C) 2020 by the authors; licensee Growing Science, Canada

\section{Introduction}

Ensuring effective socio-economic development of Ukraine regions is an important prerequisite for the economic growth of the state. It necessitates the provision of conditions and strategic priorities for the intensification of the regions' economic development, taking into account their natural resource, economic, scientific, technical, and labor potential. Each region is interested in achieving economic growth, which is possible with the effective use of the competitive advantages of the territories. The imbalance of macroeconomic policy and economic decisions taken at the state level is mostly seen at the regional level (Chirinko, \& Wilson, 2008). The development of the market environment, the economy adaptation capacity, structural reforms, the growth of innovation and investment potential, and other relevant trends in the reform of the national economy at the regional level give rise to different contradictions. Their solution requires the definition of problems and patterns of regional socio-economic development.

\section{Literature review}

A number of specialists note that investments has significantly decreased worldwide in 2008 due to the financial crisis (Dixit, 2011). To ensure liquidity in the market and restore the economy, governments around the world have implemented various

$*$ Corresponding author

E-mail address: andrusivu@ukr.net (U. Andrusiv) 
policies, including a monetary policy of quantitative easing, which has led to rather mixed results. In China, in order to counteract the financial crisis impact and stabilize the economy, the government in 2008 initiated a package of economic incentives in the amount of four trillion yuan ( 586.68 billion US dollars). Unlike the US, where the government provided high liquidity in the market, here the funds were used to promote investment in priority areas such as housing, rural infrastructure, transportation, health and education, environment, industry, disaster recovery, tax cuts, and finances (Aisbett et al., 2010). Such measures gave the opportunity to fix a number of important conclusions for scientists. First, the government has invested directly in the priority areas, thus creating demand for extractive and processing enterprises, which affected the investment of the firms. Second, this has a positive effect on the growth of consumer loans. As a result, it is easier for firms to access bank loans with a lower interest rate, which will ensure sufficient investments financing. Third, it has positively influenced the development of the regions, as it provided the motivation for scaling up the business due to its development in the regions. Europe regions have always been distinguished by a high level of investment attraction. Some scientists explained this phenomenon in the framework of the traditional neoliberal model (Robinson, 2005). A number of authors argue that only a high return on investment per capita is important for a successful capital raising (Blume et al., 1984; Cole, \& English, 1991; Casella, 1996). Representatives of the institutional approach argue that the most important role is played by standards that reduce the risk of uncertainty (Rogoff, 1985; Mattli, 2001; Kydland, \& Prescott, 1980; Thomas \& Worrall, 1994).

Especially it is necessary to allocate representatives of the ecological approach. Thus, Damania (2001) analyzed the role of investments in state environmental regulation at the regional level. Sappideen et al. (2015), Franck and Wylie (2015) studied the effects of environmental regulation in the automotive industry on the investment at the regional level. According to their work, the US automotive industry used investment choices in order to influence the development of environmental standards at the state level. A key aspect of Dijkstra (2007) is that the government's regulatory choice will depend on the strategic investments made by large investors. Cole et al. (2006) found additional evidence that additional foreign direct investment (FDI) could weaken the environmental regulation, especially in countries with high corruption level. The current state, trends, problems, and strategic priorities of the socio-economic development of Ukraine regions are analyzed in the works of Varnalia (2005), Klyianenko (2008), Reshetylo (2009) and Gerasimchuk (2011). Scientific publications by Butko (2006), Dolyshniy (2006) and Melnyk (2015) are devoted to the study and analysis of various aspects of the regional policy formation and the disproportionality of regional development. The scientific researches by Stechenko (2007) cover a problem of regional development mechanisms' activation using the economic and mathematical models and methods for improving the management of economic processes. Kinash et al. (2019) and Dovgal et al. (2017) proposed ways to activate innovative activity of the Ukrainian economy. To date, the unresolved problems of regional development are as follows: excessive disproportionality and structural imbalances, redistribution of resources and capital in favor of the same territories. These problems increase the imbalance of spatial and economic processes and continue to remain. That is why the study of the regional socio-economic development peculiarities, the definition of the influence factors on the development efficiency increase are extremely important scientific and practical tasks. They serve as the basis for ensuring the effective functioning and successful development of the country's economy as a whole. The main objective of this study is to assess the impact of the investment and innovation component on the economic development of Ukraine regions using one of the taxonomy methods. This modified developmental method allows determining the object state level in a general set of objects, and ordering the objects according to growth or decrease of this indicator. Achieving this goal means solving the following tasks:

- to substantiate the need to assess the dynamics of regional economic development level in order to identify the reserves and capacity for increasing profitability and efficiency of further activities;

- to define an integrated indicator of regional development level and formulate criteria for the development quality;

- to conduct a comparative analysis of regional economic development within the framework of the chosen model.

\section{Results and discussion}

Under the conditions of the interregional disproportionality increase and the search for ways to minimize the negative effects of territorial unevenness, there is a need to assess the dynamics of regional economic development level in order to identify the reserves and capacity for increasing profitability and efficiency of further activities. The purpose of constructing these models is to assess the state of one or another group of indicators in the annual time period. Since each group of partial indicators of the regional economic development level is a multi-dimensional economic system, we propose to use one method of taxonomy - a method of modified development level. The taxonomic procedures are most often used to compare objects that are characterized by a large number of indicators. One of the first methods of studying multidimensional objects was proposed by Helvig (Plyuta, 1980). Taxonomic development level is a synthetic value, which allows us to arrange elements of this set. The advantage of using this method is that it allows determining the object state level in a general set of objects, and ordering the objects according to growth or decrease of this indicator, since its values vary in the range from 0 to 1 . There are regular and modified levels of development. At the regular level of development, the higher the indicator, the less developed is the object. At the modified level - on the contrary, the higher the indicator, the better is the object. In addition, the analysis of literary sources has shown that most economic processes are subordinated to the normal law of quantities distribution. Since the range of the integral index varies from 0 to 1 , the average value corresponds to a value of 0.5 . In this regard, let us assume that a region with an integral index of less than or equal to 0.5 is in the stage of rapid crisis development and needs crisis management. Thus, if the index is more than 0.5 -a region is in the stage of preventive management. 


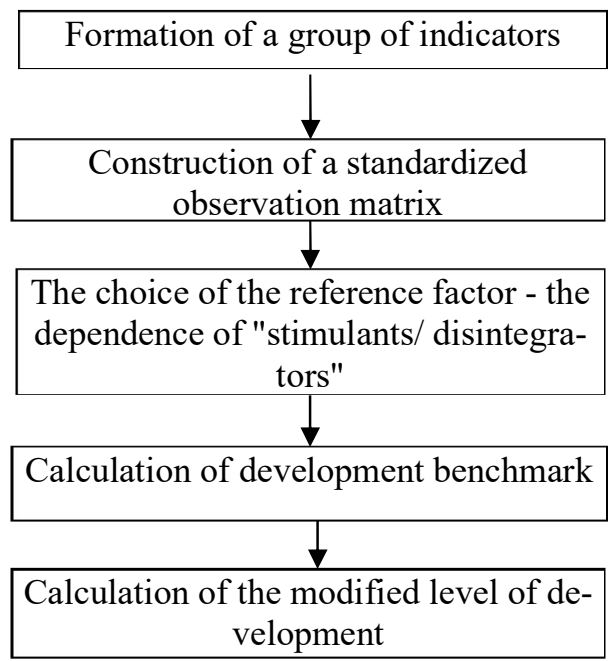

Fig. 1. Algorithm of the modified development level definition

Source: compiled by authors on the basis of V. Plyuta (Plyuta, 1980)

So, before turning to the help of comparative analysis methods, it is necessary to make certain transformations that are identical regardless of whether taxonomic procedures or methods of factor analysis will be used. The process of constructing taxonomic indicators of the development level begins with the definition of the matrix X elements observation (formula 1). Elements of this matrix are the indicators' values, which are expressed in units specific for each indicator. Therefore, it is necessary to conduct standardization. This procedure leads both to the elimination of measurement units, and to the alignment of the indicators' values. Given the set of elements $w$ described by n-characters, each unit can be interpreted as the point of the $n$-dimensional space with coordinates that are equal to the value of $n$ attributes for the unit under consideration. Let us depict the matrix as follows:

$$
X=\left[\begin{array}{l}
x_{11} x_{12} \ldots x_{1 k} \ldots x_{1 n} \\
x_{21} x_{22} \ldots x_{2 k} \ldots x_{2 n} \\
\ldots \ldots \ldots \ldots \ldots \ldots \ldots \ldots \\
x_{i 1} x_{i 2} \ldots x_{i k} \ldots x_{i n} \\
\ldots \ldots \ldots \ldots \ldots \ldots \ldots \\
x_{w 1} x_{w 2} \ldots x_{w k} \ldots x_{w n}
\end{array}\right],
$$

where $w$ - number of years (in this case, ten - 2005-2014), $n$ - quantity, $x_{i k}$ - value of the index $k$ for the year $i(k=1 / n, i=$ $1 / w)$. Indicators included in the observation matrix are heterogeneous, since they describe various properties of objects. In addition, their units are different, which complicates the execution of certain arithmetic operations necessary in individual cases. Therefore, it is necessary to perform preliminary transformations, which consist in the standardization of attributes. These transformations take place according to the formula:

$$
z_{i k}=\frac{x_{i k}-\bar{x}_{k}}{s_{k}},
$$

while

$$
\begin{aligned}
& \bar{x}_{k}=\frac{1}{w} \sum_{i=1}^{w} x_{i k}, \\
& s_{k}=\left[\frac{1}{w} \sum_{i=1}^{w}\left(x_{i k}-\bar{x}_{k}\right)^{2}\right]^{\frac{1}{2}},
\end{aligned}
$$

where $x_{k}$-arithmetic mean of $k ; s_{k}$-standard deviation of $k ; z_{i k}$ - the standardized value of $k$ for year $i$.

The next step in the consideration is the question of the observation matrix indicators differentiation. All variables are divided into stimulants and de-stimulators. The basis of the indicators division into two groups is the nature of their impact on the 
studied indicators' development level. Positive indicators that stimulate the influence on the objects' development level are called stimulants, in contrast to de-stimulators that have a negative effect, "inhibit". The distribution of indicators for stimulants and de-stimulators serves as the basis for constructing a so-called developmental standard, which is a point $P_{o}$ with coordinates: $z_{01}, z_{02}, \ldots ., z_{0 n}$,

$$
\begin{aligned}
& z_{0 s}=\max _{r} z_{r s}, \text { when } s \in I, \\
& z_{0 s}=\min _{r} z_{r s}, \text { when } s \notin I(s=1, n),
\end{aligned}
$$

where $I$ - a set of stimulants - indicators that have a positive impact on the industry, $z_{r s}$ - the standardized value of $s$ of a specific field for the year $r$. The distance between the individual points-units and the $P_{o}$ point, which represents the developmental standard, is denoted as $c_{i o}$ and is calculated as follows:

$$
C_{i 0}=\left[\sum_{s=1}^{n}\left(z_{i s}-z_{0 s}\right)^{2}\right]^{\frac{1}{2}} \quad(i=1, w) .
$$

The resulting distances are the output values that we will use to calculate the modified development rate:

$$
\begin{aligned}
& d_{i}=1-\frac{c_{i 0}}{c_{0}}, \\
& c_{0}=\frac{1}{w} \sum_{i=1}^{w} c_{i 0}, \\
& S_{0}=\left[\frac{1}{w} \sum_{i=1}^{w}\left(c_{i 0}-c_{0}\right)^{2}\right]^{\frac{1}{2}},
\end{aligned}
$$

The resultant indicator of the regional economic development level in Ukraine is the gross regional product (GRP). At the same time, we note that the necessary prerequisite for a stable economic development and ensuring high-quality economic growth in the state is high investment activity, which is achieved not only through increased investment resources, but also through their effective use in the priority sectors of the economy (Sappideen, \& He, 2015). An intensification of innovation processes, the introduction of new types of innovation products and high-tech technology is the key to the development of the economy, its ability to meet the needs of the market and implement strategic priorities. The level of investment and innovation activity determines the pace of economic growth and causes structural changes in the region's economy. As a result of the analysis, a group of indicators characterizing a comparative review of the development level was formed. Its purpose is to determine the place of the analyzed region in the total set of Ukrainian regions (Table 1).

Table 1

The indicators system that reflects the level of the region socio-economic development

\begin{tabular}{cc}
\hline Indicator & Comparative review \\
\hline $\mathrm{F}^{+}$ & Gross regional product, mln. UAH \\
$\mathrm{F}^{+}$ & Capital Investments, mln. UAH \\
$\mathrm{F}^{+}$ & Foreign direct investment, mln. USD \\
$\mathrm{F} 4^{+}$ & The volume of expenses for innovation activity, ths. UAH \\
$\mathrm{F}^{-}$ & Number of innovative enterprises, units \\
$\mathrm{F} 6^{-}$ & Number of titles of introduced innovative types of products, units \\
$\mathrm{F} 7^{-}$ & Number of scientific organizations, units \\
$\mathrm{F} 8^{+}$ & Scope of work performed by scientific organizations, ths. UAH \\
\hline $\begin{array}{l}\text { Notes: "+" - factors stimulators; "-" - factors de-stimulators. } \\
\text { Source: compiled by authors }\end{array}$
\end{tabular}

Source: compiled by authors

The factors that led to the construction of a comprehensive model for assessing the overall level of regional development are the corresponding annual values of indicators. Integrated model for assessing the modified level of the region's development:

$$
R^{T o t}=f(\mathrm{~F} 1 ; \mathrm{F} 2 ; \mathrm{F} 3 ; \mathrm{F} 4 ; \mathrm{F} 5 ; \mathrm{F} 6 ; \mathrm{F} 7 ; \mathrm{F} 8)
$$

The results are interpreted as follows: the closer the development level value to 1, the more advanced is the group of indicators. An indicator of the development level serves as a statistical characteristic of many objects. With its help, it is possible to assess the achievement of the "average" level of the indicators' values that characterize the problem under study. Using the algorithm described above for determining the development level, we find the level of development of individual regions and Ukraine as a whole. The level of socio-economic development of the studied regions and Ukraine in annual terms is presented in Table 2. 
Table 2

Integral indicator of the development level of regions and Ukraine

\begin{tabular}{|c|c|c|c|c|c|c|c|c|c|c|}
\hline Regions & 2008 & 2009 & 2010 & 2011 & 2012 & 2013 & 2014 & 2015 & 2016 & 2017 \\
\hline Ukraine & 0,194 & 0,313 & 0,498 & 0,571 & 0,544 & 0,612 & 0,618 & 0,61 & 0,664 & 0,629 \\
\hline Vinnitsa region & 0,365 & 0,408 & 0,002 & 0,37 & 0,478 & 0,461 & 0,427 & 0,431 & 0,379 & 0,476 \\
\hline Volyn region & 0,172 & 0,243 & 0,284 & 0,594 & 0,597 & 0,339 & 0,385 & 0,418 & 0,496 & 0,314 \\
\hline Dnipro region & 0,135 & 0,317 & 0,513 & 0,638 & 0,597 & 0,516 & 0,642 & 0,625 & 0,643 & 0,624 \\
\hline Donetsk region & 0,073 & 0,197 & 0,3 & 0,392 & 0,28 & 0,288 & 0,379 & 0,337 & 0,297 & 0,352 \\
\hline Zhytomyr region & 0,097 & 0,122 & 0,548 & 0,704 & 0,627 & 0,419 & 0,43 & 0,514 & 0,513 & 0,54 \\
\hline Transcarpathian region & 0,342 & 0,244 & 0,287 & 0,376 & 0,405 & 0,428 & 0,501 & 0,506 & 0,507 & 0,516 \\
\hline Zaporizhzhia region & 0,272 & 0,34 & 0,499 & 0,618 & 0,54 & 0,714 & 0,596 & 0,679 & 0,688 & 0,656 \\
\hline Ivano-Frankivsk region & 0,179 & 0,329 & 0,308 & 0,38 & 0,059 & 0,345 & 0,257 & 0,348 & 0,322 & 0,353 \\
\hline Kyiv region & 0,344 & 0,408 & 0,601 & 0,526 & 0,65 & 0,639 & 0,771 & 0,819 & 0,729 & 0,654 \\
\hline Kirovograd region & 0,286 & 0,225 & 0,412 & 0,289 & 0,284 & 0,184 & 0,348 & 0,286 & 0,361 & 0,274 \\
\hline Lugansk region & 0,064 & 0,08 & 0,291 & 0,342 & 0,142 & 0,188 & 0,218 & 0,225 & 0,251 & 0,223 \\
\hline Lviv region & 0,265 & 0,411 & 0,418 & 0,652 & 0,53 & 0,607 & 0,723 & 0,71 & 0,627 & 0,579 \\
\hline Mikolayiv region & 0,235 & 0,302 & 0,375 & 0,489 & 0,576 & 0,533 & 0,477 & 0,43 & 0,635 & 0,525 \\
\hline Odessa region & 0,095 & 0,1 & 0,632 & 0,469 & 0,416 & 0,405 & 0,379 & 0,439 & 0,471 & 0,429 \\
\hline Poltava region & 0,334 & 0,369 & 0,413 & 0,643 & 0,598 & 0,541 & 0,62 & 0,728 & 0,719 & 0,679 \\
\hline Rivne region & 0,023 & 0,331 & 0,343 & 0,686 & 0,397 & 0,288 & 0,363 & 0,408 & 0,395 & 0,33 \\
\hline Sumy region & 0,249 & 0,281 & 0,501 & 0,586 & 0,409 & 0,376 & 0,507 & 0,555 & 0,587 & 0,557 \\
\hline Ternopil region & 0,004 & 0,141 & 0,317 & 0,515 & 0,423 & 0,357 & 0,329 & 0,322 & 0,309 & 0,348 \\
\hline Kharkiv region & 0,356 & 0,4 & 0,506 & 0,583 & 0,584 & 0,617 & 0,777 & 0,711 & 0,62 & 0,516 \\
\hline Kherson region & 0,087 & 0,227 & 0,512 & 0,606 & 0,487 & 0,285 & 0,306 & 0,342 & 0,302 & 0,288 \\
\hline Khmelnitsky region & 0,106 & 0,219 & 0,358 & 0,52 & 0,63 & 0,276 & 0,289 & 0,335 & 0,352 & 0,402 \\
\hline Cherkassy region & 0,22 & 0,229 & 0,447 & 0,366 & 0,515 & 0,402 & 0,392 & 0,421 & 0,527 & 0,54 \\
\hline Chernivtsi region & 0,108 & 0,267 & 0,349 & 0,64 & 0,548 & 0,483 & 0,47 & 0,506 & 0,588 & 0,515 \\
\hline Chernihiv region & 0,247 & 0,308 & 0,397 & 0,486 & 0,284 & 0,238 & 0,308 & 0,366 & 0,435 & 0,419 \\
\hline Kyiv city & 0,35 & 0,511 & 0,582 & 0,686 & 0,669 & 0,802 & 0,792 & 0,843 & 0,923 & 0,791 \\
\hline
\end{tabular}

Source: calculated by authors based on State Statistics of Ukraine: (Official site of the State Statistics Committee of Ukraine., n.d.; State Statistics Committee of Ukraine 2017).

Having ranged the regions by the mean values of the obtained integral indicators of the development level, and received three groups of regions, in Figs. 1-3 we can show their dynamics in the integral development level indicator.

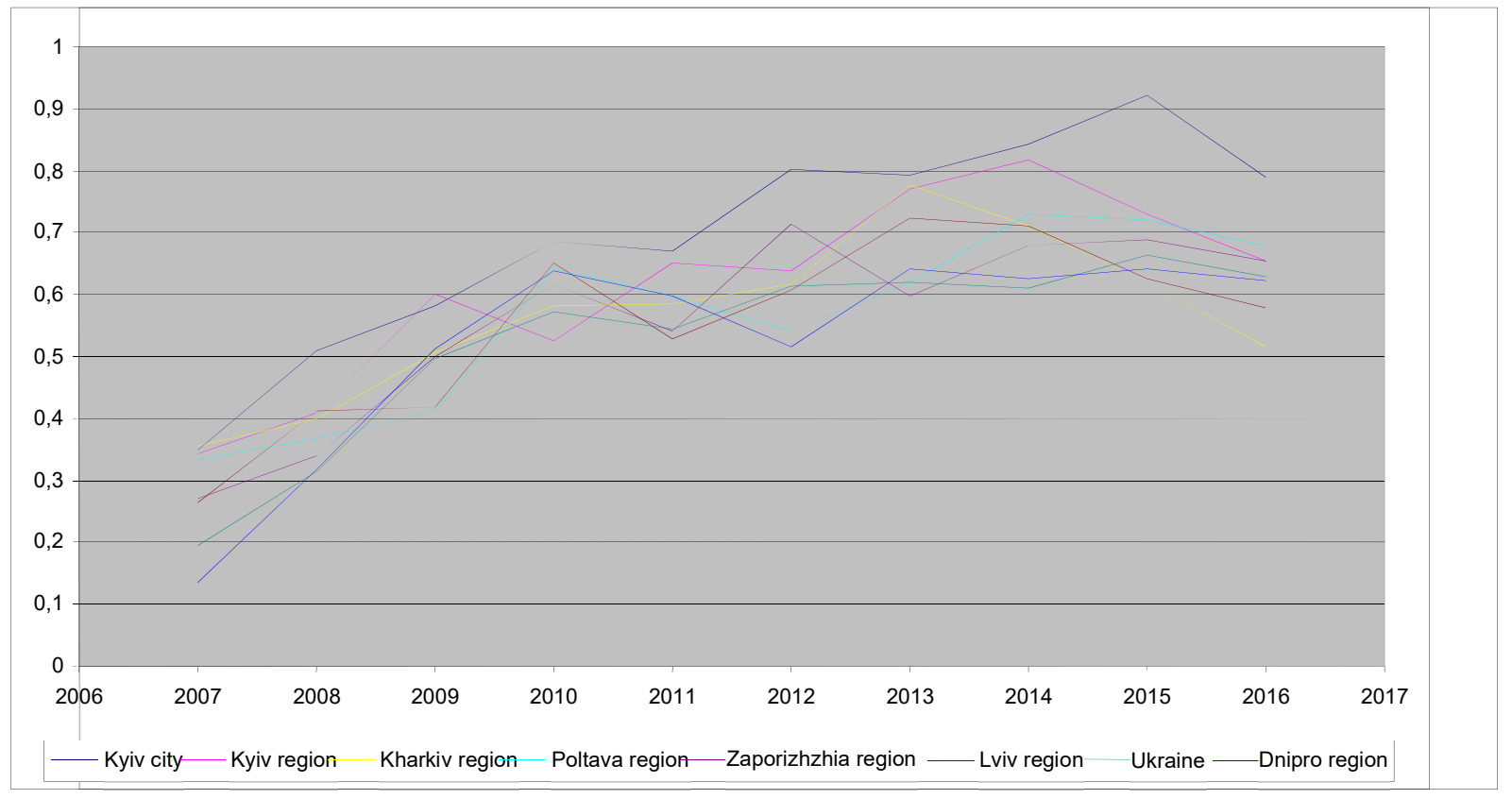

Fig. 1. Dynamics of the modified level of regional development with an average value of the integral indicator more than 0.5 Source: compiled by authors 


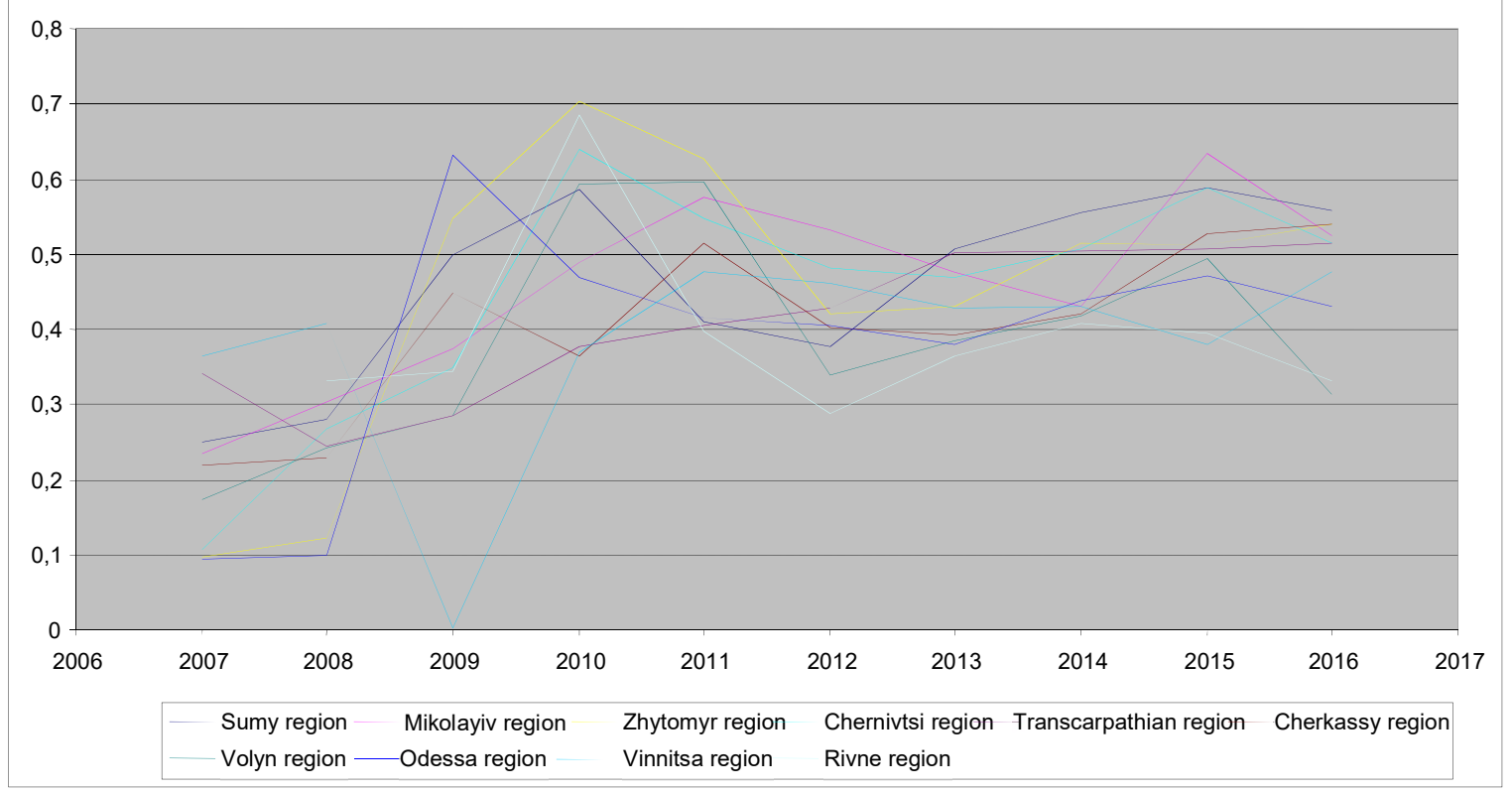

Fig. 2. Dynamics of the modified level of regional development with an average value of the integral indicator from 0.35 to 0.5

Source: compiled by authors

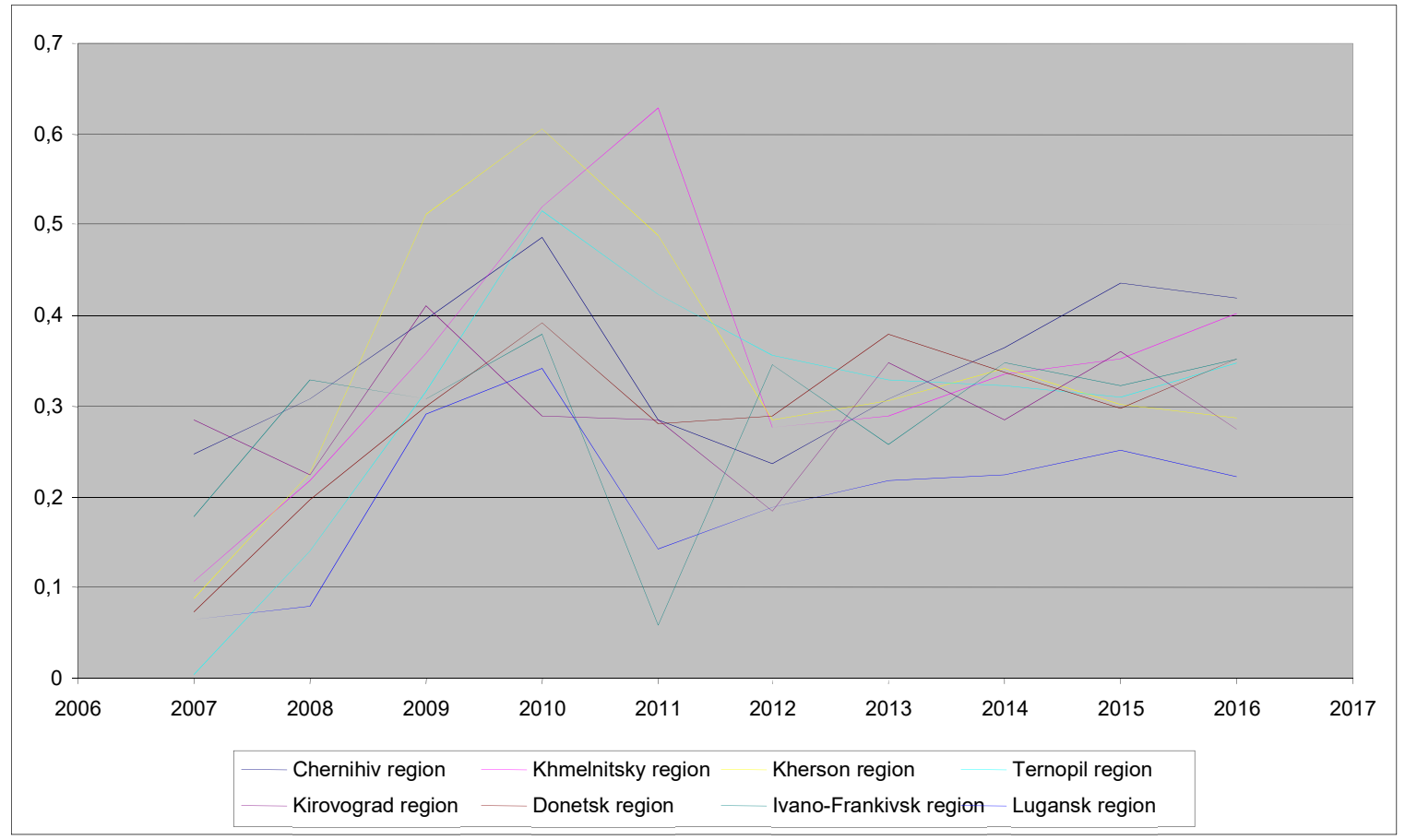

Fig. 3. Dynamics of the modified level of regional development with an average value of the integral indicator less than 0,35 Source: compiled by authors

Let us analyze the tightness of the link between the individual levels of regional development and the overall development level of Ukraine, which will use the pair correlation coefficient (Table 3). 
Table 3

The tightness of the link between the individual levels of regional development and the overall development level of Ukraine

\begin{tabular}{cccc} 
Regions of Ukraine & $\begin{array}{c}\text { The pair correlation coefficient } \\
\text { value }\end{array}$ & Regions of Ukraine & The pair correlation coefficient value \\
\hline Vinnitsa region & 0,1889 & Odessa region & 0,7726 \\
Volyn region & 0,6264 & Poltava region & 0,8833 \\
Dnipro region & 0,9598 & Rivne region & 0,6041 \\
Donetsk region & 0,8848 & Sumy region & 0,8379 \\
Zhytomyr region & 0,795 & Ternopil region & 0,8139 \\
Transcarpathian region & 0,753 & Kharkiv region & 0,8224 \\
Zaporizhzhia region & 0,9669 & Kherson region & 0,4764 \\
Ivano-Frankivsk region & 0,3328 & Khmelnitsky region & 0,5588 \\
Kyiv region & 0,8823 & Cherkassy region & 0,8281 \\
Kirovograd region & 0,173 & Chernivtsi region & 0,9026 \\
Lugansk region & 0,7101 & Chernihiv region & 0,4596 \\
Lviv region & 0,8886 & Kyiv city & 0,9536 \\
Mikolayiv region & 0,8787 & & \\
\hline
\end{tabular}

Source: calculated by authors

The analysis of data in Table 3 shows that the Dnipro, Zaporizhzhya, Chernivtsi regions and Kyiv city have the highest tightness of the link between the individual levels of regional development and the overall development level of Ukraine. Therefore, particular attention should be paid to such regions in order to develop and improve them for increasing the overall level of Ukraine development. The results of our work indirectly confirm a number of other hypotheses expressed in other articles. For example, the results of one work (Leicht, \& Jenkins, 2017) support an entrepreneurial strategy, suggesting that governments can accelerate the development of high technologies by adopting market support programs that complement private sector initiatives. In addition to this, our work positively confirms the works, where the positive impact of entrepreneurial programs is shown on changes in high-tech employment, coupled with existing localization and agglomeration benefits (Nakano et al., 2017; Haven, \& Khrennikova, 2018). In addition, we indirectly confirm that rural areas (i.e., low population density) tend to benefit from government technology development programs (Bevis, et al., 2017). Infrastructure strategy programs also contribute to the growth of high technology jobs, where local benefits already exist. Our results suggest that critics of industrial policy are right in that the growth of high technology is organic and endogenous, but governments can "choose winners and losers" in order to develop their local economy.

\section{Conclusions}

Thus, the proposed model has made it possible to trace the causes of the negative phenomena occurrence in the regional activity, to prevent their emergence, and to develop a complex of appropriate managerial influences to provide the state with a positive development vector. The practical significance of the research results is that this technique can be used to assess the development level as a separate indicator (or group), as well as the region as a whole, with further identification of interactions and influences between factors. The obtained results allow us to specify certain groups of indicators, the improvement of which will increase the overall level of the object development. Subsequently, this technique can also be used to compare development levels of several industries and to identify the most promising ones for improving the region's development.

\section{References}

Aisbett, E., Karp, L.S. \& McAusland, C. (2010). Police Powers, Regulatory Takings and the Efficient Compensation of Domestic and Foreign Investors. Economic Record, 86(274), 367-383.

Bevis, Leah E.M., Conrad, J.M., \& Barrett, Christopher B., \& Gray, C. (2017). State-conditioned soil investment in rural uganda. Research in Economics, 71(2), 254-81.

Blume, L., Rubinfeld, D., \& Shapiro P. (1984). The Taking of Land: When Should Compensation Be Paid? Quarterly Journal of Economics, 99(1), 71-92.

Butko, M.P. (2006). Regional Management, An Innovative Approach: Manual for Graduate Students. Kyiv: Znannya Ukrainy.

Casella, A. (1996). On Market Integration and the Development of Institutions: The Case of International Commercial Arbitration. European Economic Review, 40(1), 155-86.

Chirinko, R.S., \& Wilson D.J. (2008). State investment tax incentives: A Zero-Sum Game? Journal of Public Economics, 92(12), 2362-2384.

Cole, H.L., \& English, W.B. (1991). Expropriation and direct Investment. Journal of International Economics, 30(3-4), 201227.

Cole, M.A., Elliott, R.J., \& Fredriksson, P.G. (2006). Endogenous pollution havens: Does FDI influence environmental regulations? The Scandinavian Journal of Economics, 108(1), 157-178.

Damania, R. (2001). When the weak win: The role of investment in environmental lobbying. Journal of Environmental Economics and Management, 42(1), 1-22. 
Dijkstra, B. R. (2007). An Investment Contest to Influence Environmental Policy. Resource and Energy Economics, 29 (4), $300-324$.

Dixit, A. (2011). International trade, foreign direct investment, and security. Annual Review of Economics, 3(1), $191-213$.

Dolishniy, M. (2006). Regional Policy at the Turn of the XX-XXI Centuries: New Priorities. Kyiv: Naukova dumka.

Dovgal, O. V., Kravchenko, M. V., Demchuk, N. I., Odnoshevnaya, O. A., Novikov, O. Y., Andrusiv, U. Y., Popadynets, I. R. (2017). Methods of competitiveness assessment of agricultural enterprise in Eastern Europe. Regional Science Inquiry, 9(2), 231-242.

Franck, S.D., \& Linsey, E.W. (2015). Predicting outcomes in investment treaty arbitration. Duke, LJ 65, 459.

Gerasimchuk, Z.V. \& Polishchuk,V.G. (2011). Stimulating the Sustainable Development of the Region: Theory, Methodology, Practice: Monograph. Lutsk: Lutsk National Technical University.

Haven, E., \& Khrennikova, P. (2018). A quantum-probabilistic paradigm: Non-consequential reasoning and state dependence in investment choice. Journal of Mathematical Economics, 78(C), 186-197.

Kinash, I., Andrusiv, U., Golovnia, O \& Popadynets, I. (2019). Aspects of the formation and development of innovation infrastructure in Ukraine. Management Science Letters, 9(13), 2403-2414.

Kliyanenko, B., \& Osika, O. (2008). Socio-Economic Development of the Economic Complex of the Region: Methodology and Practical Analysis. Lugansk: East Ukrainian Volodymyr Dahl National University.

Kydland, Finn E., \& Prescott E.C. (1980). Dynamic Optimal Taxation, Rational Expectations and Optimal Control. Journal of Economic Dynamics and Control, 2, 79-91.

Leicht, Kevin T., \& Jenkins, J. Craig. (2017). State Investments in High-Technology Job Growth. Social Science Research, $65,30-46$.

Mattli, Walter. (2001). Private Justice in a Global Economy: From Litigation to Arbitration. International Organization, 55 (4), 919-947.

Melnyk A.F. (2015). Mechanisms for the Implementation of Regional Structural Policy. Ternopil: Ternopil National Economic University.

Nakano, M., Takahashi, A., \& Takahashi, S. (2017). Creating Investment Scheme with State Space Modeling. Expert Systems with Applications, 81, 53-66.

Official site of the State Statistics Committee of Ukraine. n.d. "Operational Statistical Information." http://www.ukrstat.gov.ua.

Plyuta, V. (1980). Comparative Multidimen Sional Analysis in Economic Research: Methods of Taxonomy and Factor Analysis. Moscow: Statistika.

Reshetylo, V.P. (2009). Synergy of Formation and Development of Regional Economic Systems: Monograph. Kharkiv: Kharkiv National Academy of Municipal Economy.

Robinson, E. J.Z. (2005). Reassessing the interaction between investment and tenure uncertainty. Environment and Development Economics, 10(2), 143-157.

Rogoff, K. (1985). The optimal degree of commitment to an intermediate monetary target. The Quarterly Journal of Economics, 100(4), 1169-1189.

Sappideen, R., \& He, L. L. (2015). Dispute resolution in investment treaties: balancing the rights of investors and host states. Journal of World Trade, 49(1), 85-116.

State Statistics Committee of Ukraine. 2018. Scientific and Innovation Activity in Ukraine in 2017. Statistical Collection. Kyiv: State Statistics Service of Ukraine.

Stechenko D. M. (2007). Programmatic-Oriented Orientation in the Management of the Region Socio-Economic Development. Universitets'ki naukovi zapysky, 3, 167-171.

Thomas, J. \& Worrall, T. (1994). Foreign Direct Investment and the Risk of Expropriation. The Review of Economic Studies, 61(1), 81-108.

Varnalia, Z. V. (2005). Regions of Ukraine: Problems and Priorities of Socio-Economic Development: Monograph. Kyiv: Znannya.

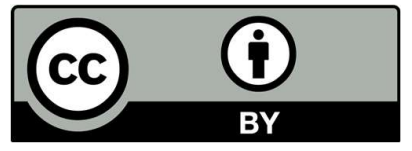

(C) 2020 by the authors; licensee Growing Science, Canada. This is an open access article distributed under the terms and conditions of the Creative Commons Attribution (CCBY) license (http://creativecommons.org/licenses/by/4.0/). 